\title{
Ultrastructural and cytochemical study on vitellogenesis in the diphyllidean cestode Echinobothrium euterpes (Echinobothriidae) and its phylogenetical implications**
}

\author{
Zdzisław Świderski ${ }^{1,2 *}$, John S. Mackiewicz ${ }^{3}$, Catarina Eira ${ }^{4,5}$ and Jordi Miquel ${ }^{6,7}$ \\ ${ }^{1}$ W. Stefański Institute of Parasitology, Polish Academy of Sciences, 51/55 Twarda Street, 00-818 Warsaw, Poland; \\ ${ }^{2}$ Department of General Biology and Parasitology, Warsaw Medical University, 5 Chałubińskiego Street, 02-004 Warsaw, Poland; \\ ${ }^{3}$ Department of Biological Sciences, State University of New York at Albany, Albany, N.Y. 12222, U.S.A.; \\ ${ }^{4}$ CESAM \& Departamento de Biologia, Universidade de Aveiro, Campus de Santiago 3810-193 Aveiro, Portugal; \\ ${ }^{5}$ Sociedade Portuguesa de Vida Selvagem, Estaçao de Campo de Quiaios, Apartado 16 EC Quiaios 3081-101 Figueira da Foz, Portugal; \\ ${ }^{6}$ Laboratori de Parasitologia, Departament de Microbiologia i Parasitologia Sanitàries, Facultat de Farmàcia, Universitat de Barcelona, \\ Av. Joan XXIII, sn, 08028 Barcelona, Spain; ${ }^{7}$ Institut de Recerca de la Biodiversitat, Facultat de Biologia, Universitat de Barcelona, \\ Av. Diagonal, 645, E08028 Barcelona, Spain
}

\begin{abstract}
The first description of vitellogenesis in the Diphyllidea is presented in this paper. Though the type of vitellogenesis and mature vitellocyte in Echinobothrium euterpes appear to be unique among the Eucestoda, however, they somewhat resemble that observed in the two orders of the lower cestodes, Tetraphyllidea and Proteocephalidea. Vitellocyte maturation is characterized by: (1) an increase in cell volume; (2) extensive development of short, parallel, frequently concentric cisternae of GER that produce dense proteinaceous granules; (3) development of Golgi complexes engaged in packaging this material; (4) progressive formation of saturated lipid droplets; their continuous enlargement and fusion; (5) formation of small accumulations of glycogen particles scattered between and among lipid droplets in the cytoplasm of maturing vitellocytes; (6) concentration of dense proteinaceous granules in the peripheral layer of cytoplasm, around the cell plasma membrane; and (7) vacuolization of cytoplasm of mature vitellocytes accompanied by a rapid increase in its volume. A new, unreported type of dense proteinaceous granules, situated around the limiting plasma membranes of mature vitellocytes, is described. Vitellogenesis evidently differs from that with typical shell-globules and shell-globule clusters previously reported in other taxa of lower cestodes. Cytochemical staining with periodic acidthiosemicarbazide-silver proteinate for glycogen indicates a strongly positive reaction for glycogen particles between and around large unsaturated lipid droplets of the maturing and mature vitellocytes. Some hypotheses concerning the interrelationship between this pattern of vitellogenesis, possible mode of egg formation, embryonic development and diphyllidean life cycle, and their phylogenetic implications are drawn and discussed.
\end{abstract}

\section{Keywords}

Cestoda, Diphyllidea, Echinobothrium euterpes, vitellogenesis, ultrastructure, cytochemistry, dense proteinaceous granules, saturated lipids, glycogen

\section{Introduction}

Review of the literature indicates that there are no published data on vitellogenesis in diphyllidean cestodes, a group much neglected in ultrastructural and cytochemical studies. As described in the extensive review on cestode vitellogenesis (Świderski and Xylander 2000), their vitellocytes have two im- portant functions: (1) formation of hard eggshell (e.g. Bothriocephalidea) or a delicate capsule (e.g. Cyclophyllidea), and (2) supplying nutritive reserves for the developing embryos. During cestode evolution, these two functions have been intensified or reduced in different taxa, depending on the type of their embryonic development, degree of ovoviviparity and differences in life cycles (Świderski and Mokhtar 1974; Świderski and

\footnotetext{
*Corresponding author: z.swider@twarda.pan.pl
}

**Dedicated to the memory of Professor Jerzy Stanisław Ruszkowski (1887-1934) in recognition for his contributions to the field of developmental biology of Diphyllidea 
Mackiewicz 1976; Świderski and Subilia 1978; Świderski and Xylander 2000; Świderski et al. 1970a, b, 2000, 2004, 2005).

The aim of this study is to provide initial information on the ultrastructural and cytochemical aspects of vitellogenesis in the diphyllidean cestode Echinobothrium euterpes, a parasite of the spiral valve of the rhinobatid ray, the common guitarfish Rhinobatos rhinobatos (L.), with particular emphasis on vitellocyte differentiation, proteinaceous granule formation, and synthesis of nutritive materials for the developing embryos.
The monograph on the Diphyllidea by Tyler (2006), the most recent source of information on this order, was a stimulating factor for undertaking the present study.

\section{Materials and methods}

Mature Echinobothrium euterpes (Neifar, Tyler et Euzet, 2001) Tyler, 2006 (Diphyllidea, Echinobothriidae) were col-

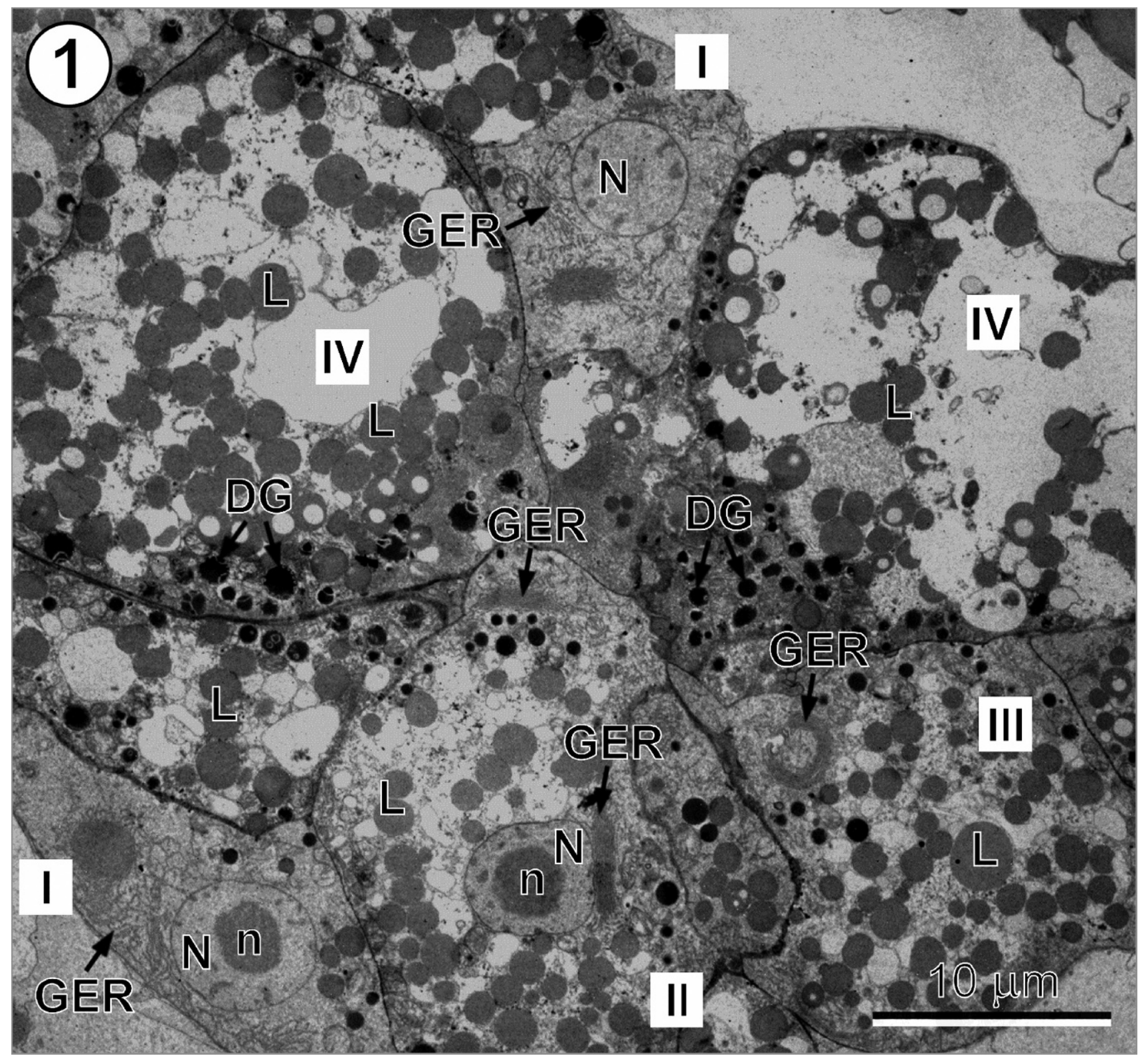

Fig. 1. Low-power electronmicrograph illustrating general topography of the vitelline follicle showing four consecutive stages of vitellogenesis in Echinobotrium euterpes: I. Immature vitellocyte of gonial type. II. Early stage of cytodifferentiation. III. Advanced stage of vitellocyte maturation. IV. Mature vitellocyte, and their localization within the follicle. Abbreviations to all figures: DG - dense proteinaceous granules, gl - glycogen, GC - Golgi complex, GER - granular endoplasmic reticulum, Hch - heterochromatin islands, L - lipid droplet, $\mathrm{m}$ - mitochondria, $\mathrm{N}$ - nucleus, $\mathrm{n}$ - nucleolus, $\mathrm{np}$ - nuclear pores, $\mathrm{v}$ - vacuoles, I - immature vitellocyte, II - early differentiation, III - advanced maturation of vitellocyte, IV - mature vitellocyte 
lected from the spiral intestine of the common guitarfish, Rhinobatos rhinobatos (L.), caught in the Mediterranean Sea, Gulf of Gabès (Tunisia). Living cestodes were dissected in a $0.9 \% \mathrm{NaCl}$ solution. Different portions of mature proglottids containing vitelline follicles and vitelloducts were processed for transmission electron microscope (TEM) study in the following manner: specimens were fixed in cold $\left(4^{\circ} \mathrm{C}\right) 2.5 \%$ glutaraldehyde in a $0.1 \mathrm{M}$ sodium cacodylate buffer at $\mathrm{pH} 7.4$ for $2 \mathrm{~h}$, rinsed in the same buffer, postfixed in cold $\left(4^{\circ} \mathrm{C}\right) 1 \%$ osmium tetroxide in the same buffer for $1 \mathrm{~h}$, rinsed again in this buffer, dehydrated in an ethanol series and propylene oxide, and finally embedded in Spurr's resin. Ultrathin sections were obtained using a Reichert-Jung Ultracut E ultramicrotome, placed on copper grids and double-stained with uranyl acetate and lead citrate. Ultrathin sections were examined using a JEOL 1010 TEM operated at an accelerating voltage of $80 \mathrm{kV}$.

For cytochemistry of glycogen, the ultrathin sections were collected on gold grids. The periodic acid-thiosemicarbazidesilver proteinate (PA-TSC-SP) technique of Thiéry (1967) was applied to determine cytochemical localization of glycogen.

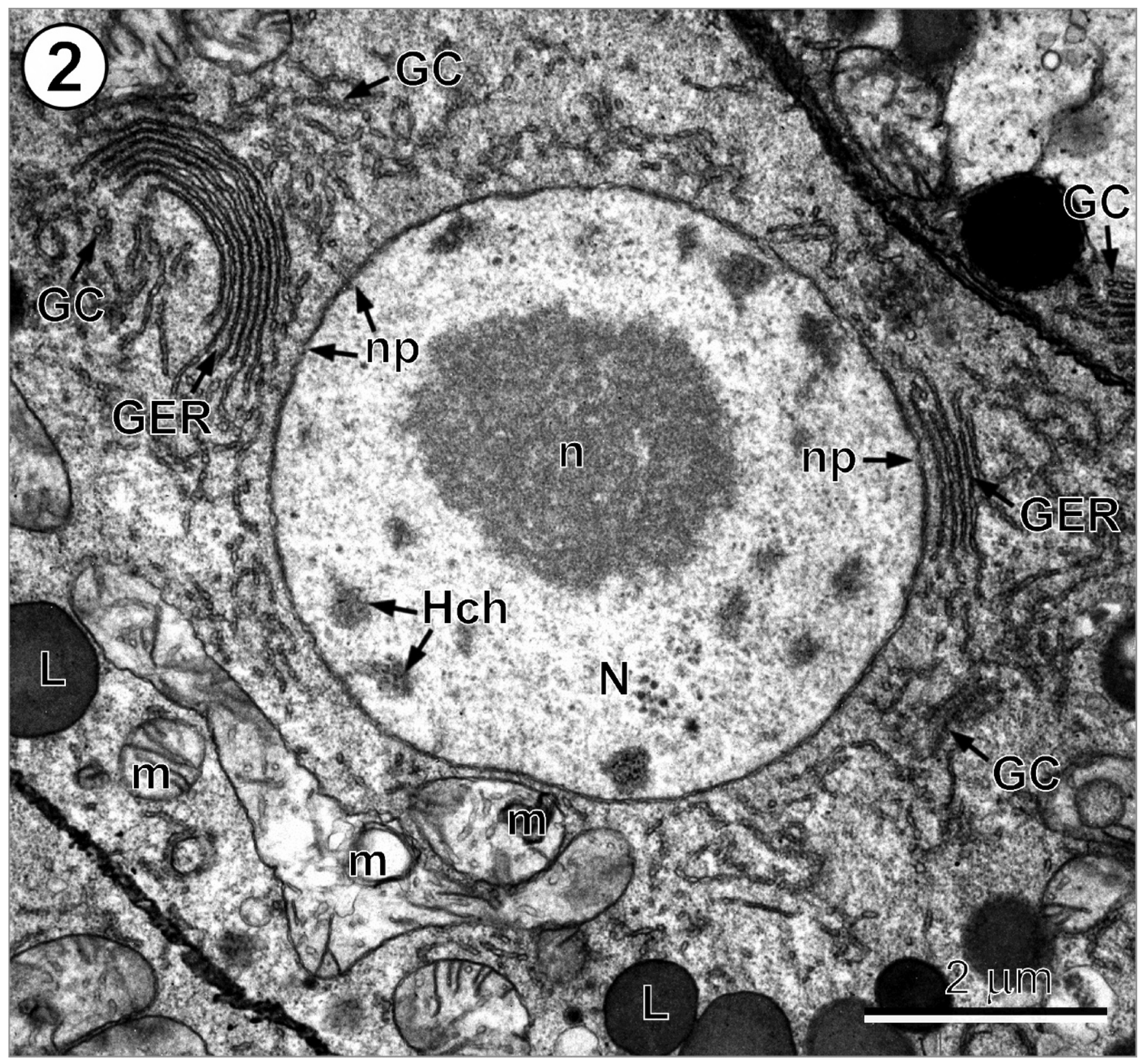

Fig. 2. High-power electronmicrograph illustrating details of the early stage II of vitellocyte differentiation. Note: (1) a large nucleus with numerous pores in nuclear membrane, prominent electron-dense nucleolus, and a few small islands of heterochromatin randomly dispersed in the nucleoplasm; (2) granular cytoplasm with several large mitochondria, short, parallel profiles of GER adjacent to Golgi complexes and a few lipid droplets 
These gold grids were also examined in a JEOL 1010 transmission electron microscope operated at an accelerating voltage of $80 \mathrm{kV}$.

The terminology used to describe vitellogenesis follows that of Świderski and Xylander (2000).

\section{Results}

\section{General topography of vitelline system}

The follicular vitellaria of $E$. euterpes are enclosed by the cortical parenchyma forming a continuous sleeve around all internal organs. They are arranged in two columns extending laterally along the longitudinal axis of the entire length of the proglottid, uninterrupted by the ovary, confluent posterior to ovary and each connected to a median vitelloduct. Each of the numerous spherical or slightly elongated vitelline follicles of a mature proglottid contains all consecutive stages of vitellogenesis.

\section{General ultrastructure}

The TEM results represent the first published accounts of vitellogenesis in the Diphyllidea. Mature vitelline follicles (Figs 1-8) consist of: (a) vitelline cells in various stages of development, progressing from immature cells of gonial type situated usually near the follicle periphery to mature vitellocytes towards the centre and (b) irregularly shaped interstitial cells. Long projections of the interstitial cells enclose the vitellocytes and extend as a cytoplasmic sheath at the periphery of vitelline follicles. The general pattern of vitellocyte development in E. euterpes is similar to that of other cestodes.

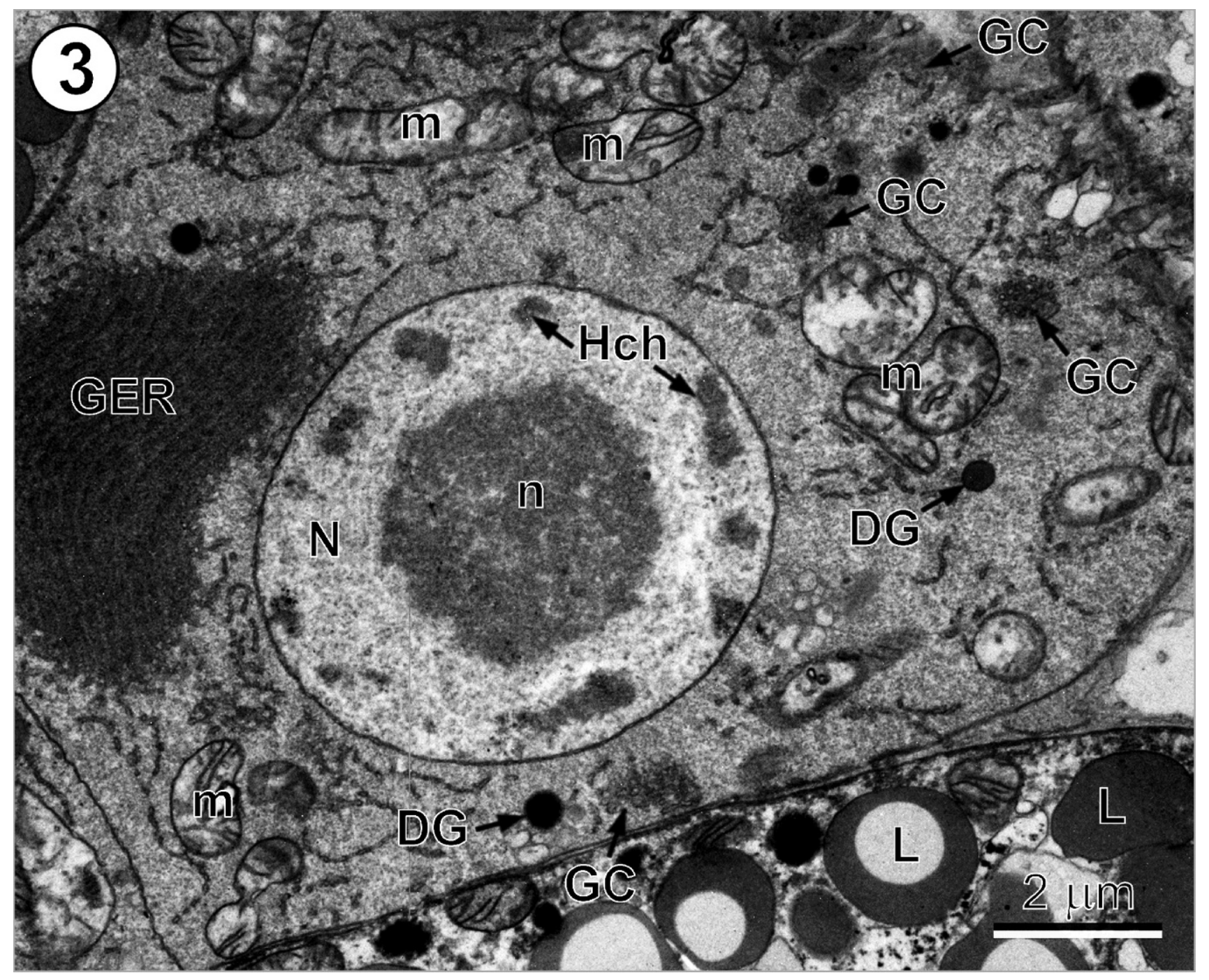

Fig. 3. More advanced stage of vitellocyte differentiation in the initial phase of formation of dense proteinaceous granules within Golgi regions adjacent to extended GER areas. Note ultrastructural details of cell organelles similar to these described above in legend to Fig. 2. Right lower corner of this micrograph shows peripheral region of adjacent mature vitellocyte 

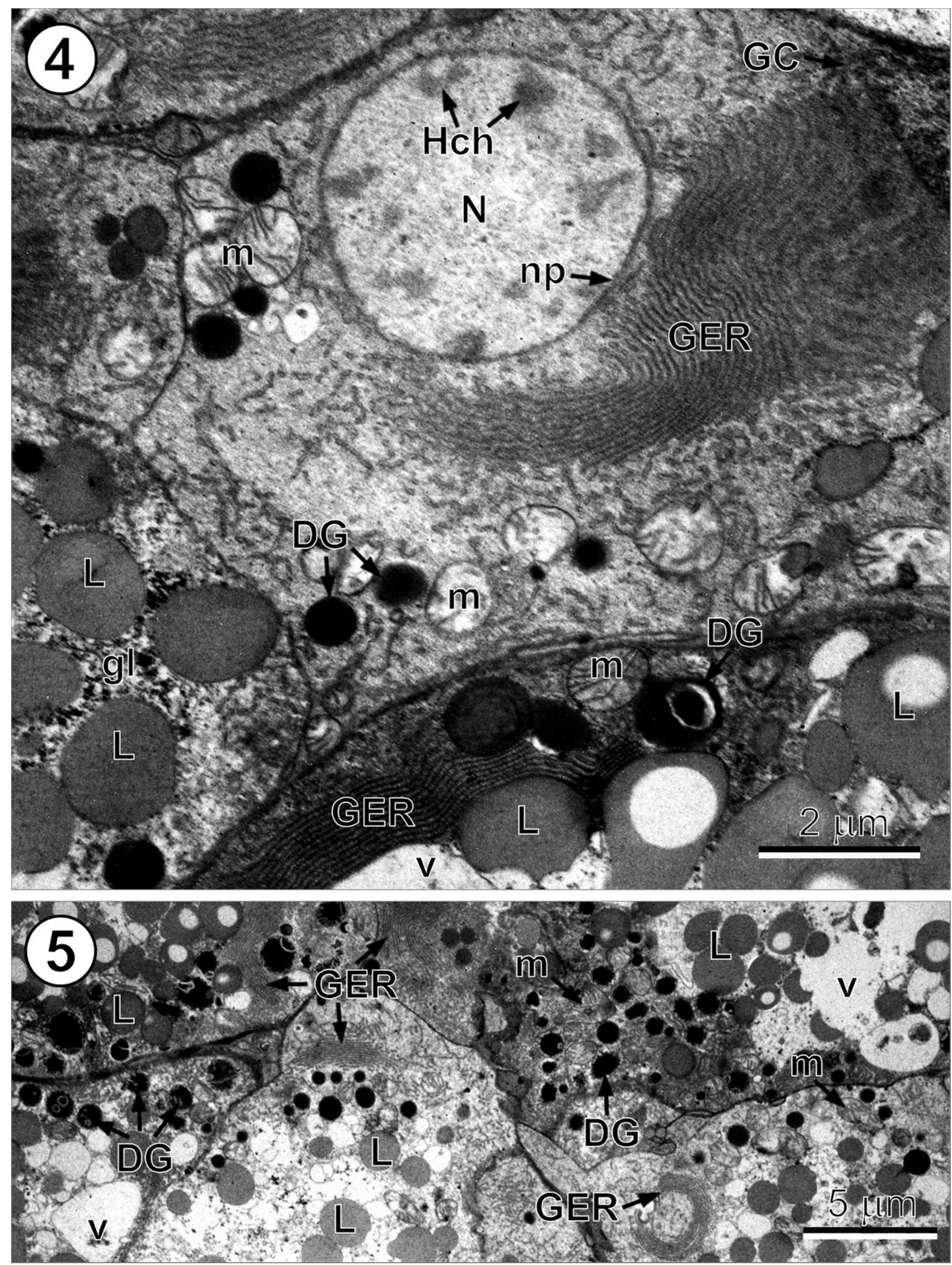

Figs 4 and 5. Beginning of the advanced maturation of vitellocyte (stage III) in the right upper part of micrograph of Fig. 4, surrounded by the peripheral cytoplasmic regions of mature vitellocytes. 5. Low-power electronmicrograph of the peripheral cytoplasmic regions of mature vitellocytes illustrating a high concentration of dense proteinaceous granules in these areas 

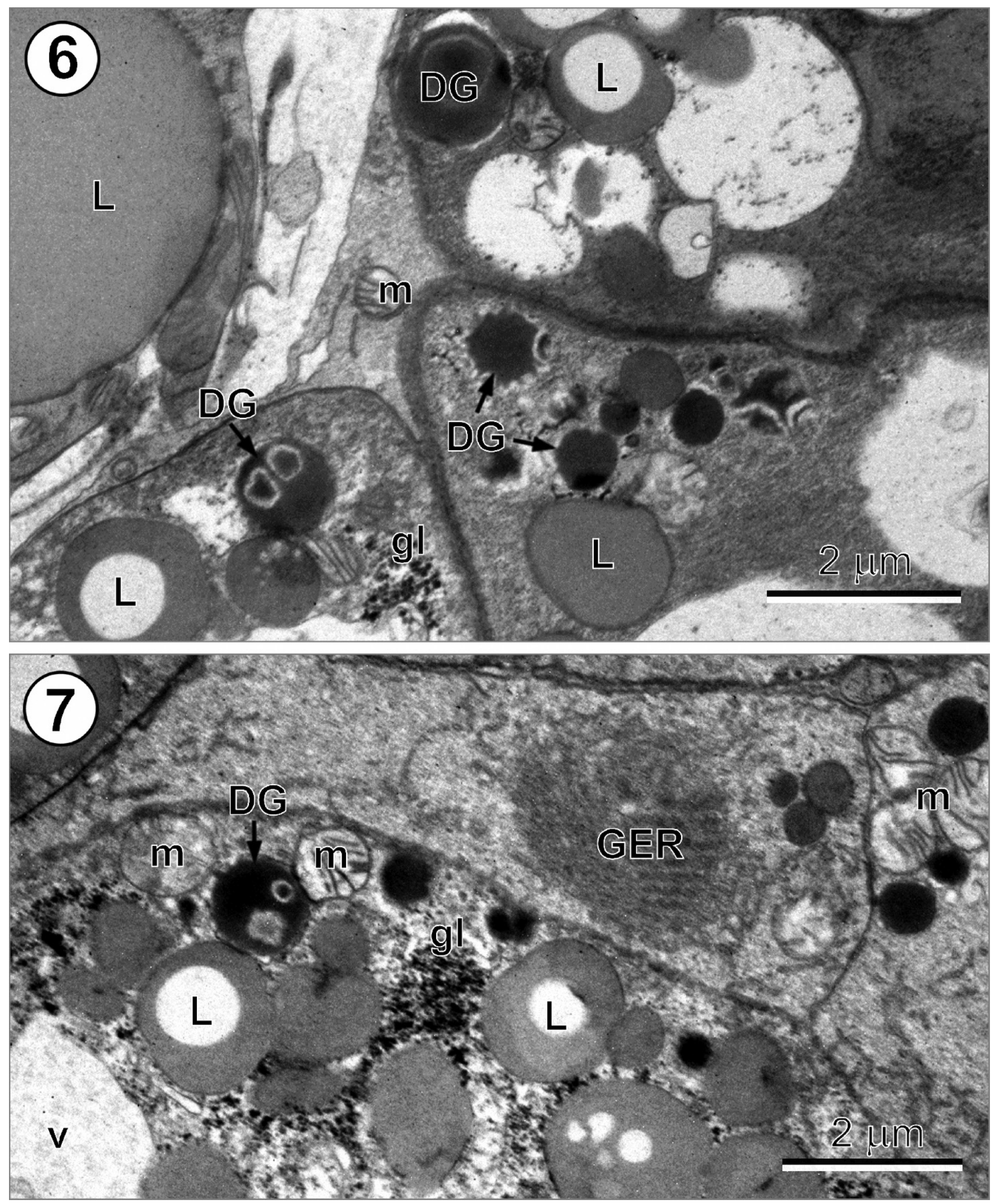

Figs 6 and 7. Results of the cytochemical test for glycogen according to Thiéry’s method showing small concentrations of particles at the cell periphery, frequently near and around large, osmiophobic lipid droplets of unsaturated chemical nature. Note "empty" circular spaces in several large lipid droplets where triglycerides were partially washed out during fixation and Thiéry's cytochemical procedure 


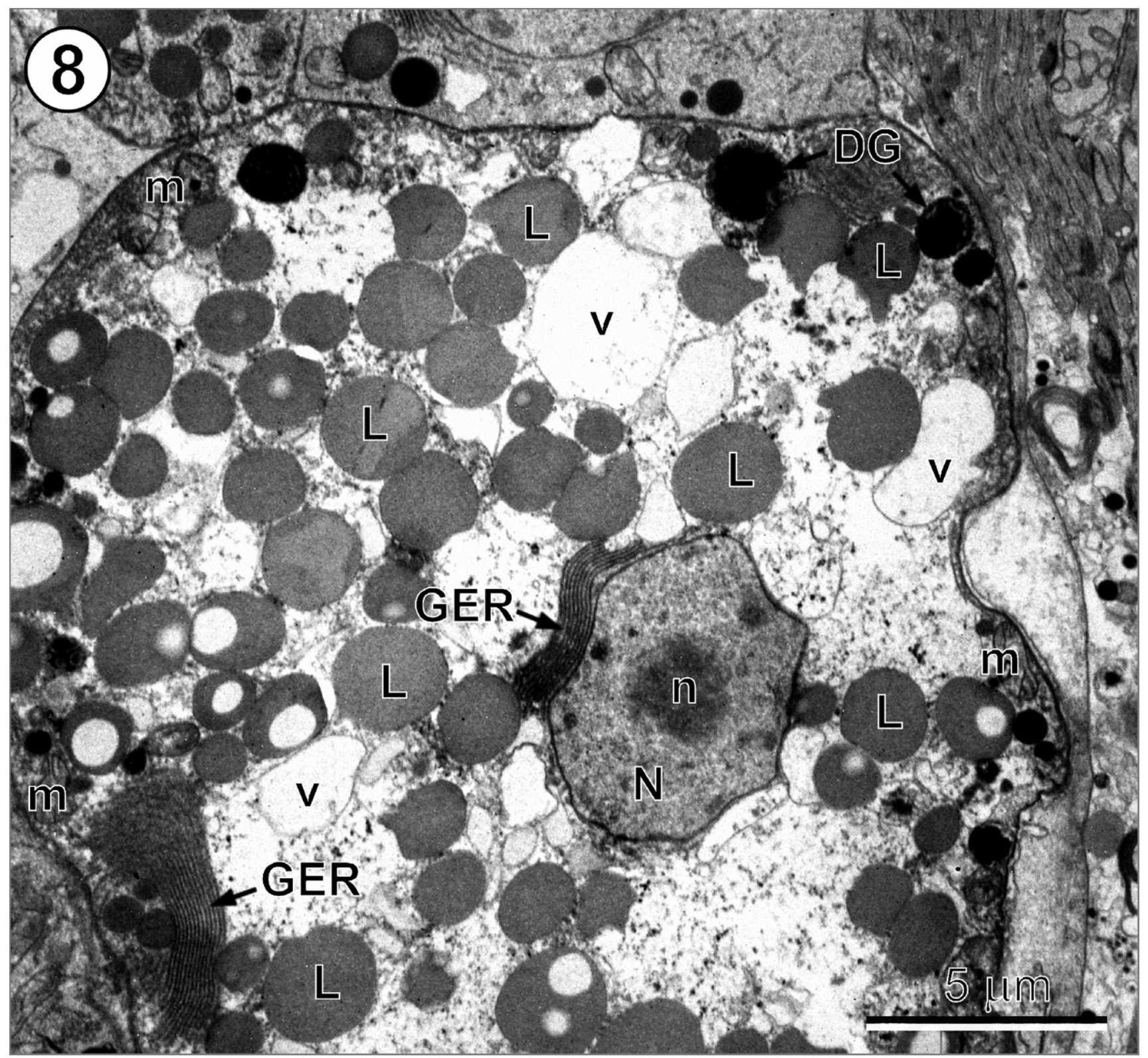

Fig. 8. Electron micrograph illustrating ultrastructual details of mature vitellocyte of E. euterpes. Note: (1) a very low nucleo-cytoplasmic ratio due to the great vacuolization of vitellocyte cytoplasm much increasing its volume and therefore the size of entire cell; (2) concentration of dark proteinaceous granules and a majority of cellular organelles such as mitochondria and GER in the peripheral layer of cytoplasm around limiting plasma membrane; (3) small, irregularly-shaped nucleus, with closely adjacent to it numerous parallel cisternae of GER, still contains spherical nucleolus and very few small islands of heterochromatin

Although vitellocyte cytodifferentiation constitutes a continuous process, it has been arbitrarily subdivided into four discrete stages to facilitate description (Świderski and Xylander (2000): (I) immature cell of gonial type; (II) early differentiation; (III) advanced maturation; and (IV) mature vitellocyte (Figs 1-8). Maturation is characterized by: (1) increase in cell volume; (2) rapid synthesis and storage of fat as a concentrated energy source in the form of large, highly osmiophobic lipid droplets which appear for the first time in stage II (Figs 1-5); (3) extensive development of elongated parallel cisternae of granular endoplasmic reticulum GER that produce vitelline material remaining in close association with Golgi complexes engaged in its packaging (Figs 2 and 4); (4) progressive formation of saturated lipid droplets; their continuous enlargement and fusion; (5) formation of small accumulations of glycogen particles scattered between and among lipid droplets in the cytoplasm of maturing vitellocytes; (6) concentration of dense proteinaceous granules in the peripheral layer of cytoplasm, around the cell plasma membrane; (7) vacuolization of cytoplasm of mature vitellocytes accompanied by a rapid increase in its volume and increase in size of the entire vitelline cell. 


\section{Immature vitellocyte (stage I)}

The undifferentiated cells of gonial type (Fig. 1) representing the precursors of vitelline cells, show a high nucleocytoplasmic ratio and a large concentration of free ribosomes in a relatively thin layer of granular cytoplasm. These immature cells, generally at the periphery of the follicle, are spherical or ovoid. The nucleus measures about $5.5 \mu \mathrm{m}$ in diameter while the diameter of the entire cell is approximately $9 \mu \mathrm{m}$. The large nuclei contain distinct spherical nucleoli of a homogeneous type and a few small islands of heterochromatin randomly dispersed in the nucleoplasm (Fig. 1). Their granular cytoplasm contains several large mitochondria with numerous long cristae (Figs 1,2). Sometimes, individual short profiles of sparse GER have also been noticed (Figs 1,2).

\section{Early phase of vitellocyte maturation (stage II)}

During the early phase of maturation the increase in cell size is accompanied by cytodifferentiation of cytoplasmic organelles involved in synthesis, transport and packaging of secretory products such as GER, mitochondria and Golgi complexes (Figs 1-3). At the onset of maturation, the nuclear pores (Figs 2 and 3) in a perforated nuclear envelope become more evident and more numerous. Several small dark, proteinaceous granules (Fig. 3) of Golgi origin were frequently observed in this phase in the regions of Golgi complexes, GER, lipid droplets and mitochondria.

\section{Advanced stage of maturation (stage III)}

This stage is characterised by a greater increase in cell size. A thick layer of granular cytoplasm is rich in numerous cell organelles and inclusions such as the extended areas of GER composed numerous cisternae in a close spatial relationship with the nucleus, large mitochondria, ribo- and polyribosomes, Golgi complexes, a few unsaturated lipid droplets of different sizes and low electron density, and several small dark, proteinaceous granules of different sizes (Fig. 4), but evidently larger than that observed in the previous phase or stage II (compare with Fig. 3). The consecutive stages of the development of dense proteinaceous granules and their transformation into dark proteinaceous granules of a heterogeneous nature composed of irregularly shaped areas of electron-dense and electron-lucent material (Fig. 4 [right lower corner]; Figs $6,7)$. A few small islands of glycogen particles situated between and around lipid droplets, which appear for the first time during advanced phase or stage III of vitellocyte maturation (Figs 6, 7).

\section{Mature vitellocytes (stage IV)}

The majority of dark, electron-dense proteinaceous granules move progressively from the perinuclear into peripheral cytoplasm of vitellocytes (Figs 5-8) and remains attached to their limiting plasma membranes (Figs 1, 5 and 8). Their electron-dense material, forming irregularly-shaped islands becomes embedded in apparently amorphous, electron-lucid material (Figs 5-7). A high concentration of these dense proteinaceous granules was observed in the peripheral layer of cytoplasm, around the cell plasma membrane of mature vitellocytes (Figs 5-8). At the same time, evident vacuolization of cytoplasm of mature vitellocytes accompanied by a rapid increase in its volume is resulting in a great increase in size of the vitelline cell.

\section{Cytochemistry}

The results of Thiéry's test with periodic acid-thiosemicarbazide-silver proteinate (PA-TSC-SP) for glycogen (Figs 6, 7) show several islands of glycogen particles situated between and around lipid droplets. These particles mainly appear for the first time during the advanced phase or stage III of vitellocyte maturation (Figs 6,7) and remain in mature vitellocytes.

During fixation with osmium tetroxide, many lipid droplets which are rich in saturated fatty acids in vitelline cells became only slightly blackened by reduction of osmium and therefore appear rather osmiophobic on ultrathin sections. The white central circles visible in some of the droplets probably represent artifacts of fixation or lipid areas where triglycerides were partially washed out during fixation and Thiéry's cytochemical procedure (Figs 1-8).

\section{Discussion}

Comparison of vitellogenesis pattern in E. euterpes and other cestodes

The vitellogenesis pattern and ultrastructure of mature vitellocytes in E. euterpes resembles to some extent that reported for tetraphyllideans (Mokhtar-Maamouri and Świderski 1976) and proteocephalideans (Świderski et al. 1978, Bruňanská 1997), the two orders of lower cestodes with eggs surrounded only by a thin, delicate capsule. Both characters differ greatly from those reported in a great majority of other lower cestode orders, such as Caryophyllidea, Spathebothriidea, Bothriocephalidea or Trypanorhyncha, that have eggs with a hard, electron-dense shell and are frequently operculate (Świderski and Mokhtar 1974; Świderski and Mackiewicz 1976; Świderski et al. 2004, 2006a, b, 2007, 2009; Bruňanská et al. 2005; Poddubnaya et al. 2006; Levron et al. 2007).

While these four cestode orders have such eggs for embryo protection and large amounts of nutritive reserves for a long period of embryonation in water, it seems that these same functions provided by vitellogenesis are greatly reduced in E. euterpes, as well as in tetraphyllideans and proteocephalideans with their embryonic development in utero.

The amount of lipids in vitellocytes is highly variable in different groups of cestodes. Their highest concentration, comBrought to you by | Universidade de Aveiro 
parable to that observed in E. euterpes, was described in vitellocytes of Tetraphyllidea (Mokhtar-Maamouri and Świderski 1976), where lipid droplets were observed not only in their cytoplasm, but frequently also in the nucleoplasm. In E. euterpes, as in tetraphyllideans (Mokhtar-Maamouri and Świderski 1976) and proteocephalideans (Świderski et al. 1978, Bruňanská 1997, Młocicki et al. 2010) vitellocytes have a great amount of saturated lipid droplets and only a very small amount of polysaccharides, mainly in the form of $\beta$-glycogen particles. On the other hand, vitellocytes of caryophyllideans are characterized by a great amount of nuclear and cytoplasmic glycogen and absence of lipid droplets (Świderski and Mackiewicz 1976; Świderski and Xylander 1998, 2000; Świderski et al. 2004). That the nature of lipids in vitellocytes of different cestode taxa may vary rises important questions regarding the factors determining lipid type, their functional significance, and role they might have in assessing evolutionary relationships.

Such differences may have an association with ecological - life cycle factors such as different environmental conditions required for intermediate hosts and/or for egg maturation. For example, while an aerobic environment is necessary for the development of tetraphyllidean, proteocephalidean and diphyllidean intermediate hosts (crustaceans), nearly anaerobic environment (mud) is required for caryophyllidean intermediate hosts (aquatic annelids, tubificids) (Świderski and Mackiewicz 1976; Świderski and Xylander 1998, 2000; Świderski et al. 2004). To the intermediate host and nutrient factors must be added the morphology of the egg as an important adaptive factor in the successful transmission of any cestode (Janicki 1918, Jarecka 1961, 1975; Mackiewicz 1988). Clearly, the type of vitellogenesis present in E. euterpes, along with nutrient reserves and egg morphology, are all related to the ecology and successful life cycle of this species. Furthermore, the nature of the nutritive reserves accumulated in the vitellocytes may also reflect the parallelism and analogies in adaptations to the parasitic way of life in different groups of cestodes (Świderski and Xylander 2000).

Comparison of vitellogenesis between cestode polylecithal and oligolecithal egg types

Two types of ectolecithal eggs can be distinguished in cestodes: polylecithal and oligolecithal. They are separated from each other according to the number of vitellocytes per oocyte and amount of vitelline material per vitellocyte. Polylecithal eggs are characterised by a very high amount of vitelline material because of two factors: (1) they contain a large number of vitellocytes, generally 20-30 per fertilised oocyte (egg), and (2) each vitellocyte has a high content of vitelline material of two distinct types and completely different functions that are: (a) precursor materials for egg shell or egg capsule formation and, (b) nutritive reserves of glycogen, lipids or mixture of both in different proportions for the developing embryo. These nutritive reserves, though generally in the vitel- locyte cytoplasm, may also be in the nucleus, as in caryophyllidean vitellocytes (Mackiewicz 1968, Świderski and Mackiewicz 1976, Świderski and Xylander 2000, Świderski et al. 2004, Bruňanská et al. 2009). Polylecithal eggs are found in the monozoic cestodes (Caryophyllidea) and other lower eucestodes as the Bothriocephalidea and Trypanorhyncha (Świderski and Xylander 2000). See Świderski et al. (2009) for a current review of vitellocyte composition of lower cestodes including Proteocephalidea and Tetraphyllidea.

Oligolecithal eggs, on the other hand, generally have only one or exceptionally two vitellocytes per one fertilised oocyte, although some exceptions do exist (Świderski and Xylander 1998, 2000). Nutrient reserves may involve glycogen and lipids but are confined to the cytoplasm. Such eggs have been described in two species of proteocephalideans (Świderski and Subilia 1978, Bruňanská 1997, Młocicki et al. 2010), and thus far examined cyclophyllideans (Świderski 1968, 1973; Świderski et al. 1970a, b, 1978, 2000, 2005).

\section{Interrelationships between functional ultrastructure of} E. euterpes vitellocytes and diphyllidean eggs

Eggs of diphyllidean cestodes correspond to oligolecithal type, based largely on the data from Rees (1961) and the monograph of Tyler (2006). Probably the most important description of the structure of diphyllidean eggs is that of Rees (1961) on Echinobothrium affine Diesing, 1863; her detailed drawings [see: her text-figs. $33-35$ on p. 220] are especially illuminating. Fully formed eggs from the uterus, consisting of a thin transparent capsule with a single appendage, have two vitellocytes, a fertilised oocyte or two pronuclei, and two polar bodies. Unfortunately, there is no light or electron microscope information available on the embryonic development of any diphyllidean species.

Careful comparison of eggs of a majority of diphyllideans included in Tyler's (2006) monograph confirm not only their oligolecithality common for all examined species (i.e. thin shelled, non-operculate), but that they also have a great variety of shapes, sizes and packaging among the different species. Furthermore, there may be different types appendages on eggs in the form of a single filament, two filaments, or a mucron at one pole of the egg. In some diphyllidean species, eggs may occur alone or in long or short chains, groups of three eggs (e.g. Echinobothrium affine Diesing, 1863) or even so-called "cocoons" or sacs of 5-10 eggs (e.g. Echinobothrium acantinophyllum Rees, 1961). Such a wide variety of egg shapes and forms suggests adaptations for a wide variety of intermediate hosts under divers ecological conditions. To what extent vitellogenesis may be related to such adaptations remains to be seen.

No complete life-cycle is known for any diphyllidean cestode, although larval stages of several species have been found in such invertebrate hosts as crustaceans and molluscs (Tyler 2006). One of these was found in the body cavity of a shrimp within the gut of a skate (Ruszkowski 1927, 1928). According to data from Tyler (2006), the key elements of a hypothesized Brought to you by | Universidade de Aveiro 
life cycle for the diphyllideans involving known intermediate hosts has: (a) eggs eaten by an amphipod or copepod where the hexacanth larva develops to a procercoid, (b) second intermediate host such as a crab or shrimp eats the crustacean and procercoid develops to the plerocercus stage, (c) a paratenic host such as a teleost may eat the second intermediate host or an elasmobranch may eat the paratenic host or the second host directly. Maturation is in the elasmobranch host. This proposed cycle is thus more like that of Bothriocephalidea or Trypanorhyncha having polylecithal eggs rather than the Proteocephalidea or cyclophyllideans with oligolecithal eggs. The egg type - life cycle - vitellogenesis relationships of the Diphyllidea clearly share features of both the "lower" and "higher" eucestodes and thus reflects the same divers conclusions of their phylogenetic relationship as reviewed by Tyler (2006).

The phylogenetic analysis published by Ivanov and Hoberg (1999) showing the relative paucity of morphological characters available for cladistic analysis on Diphyllidea stimulated our interest in making TEM studies on a few species belonging to this order.

As seen above, our work on vitellogenesis of E. euterpes has not clarified the phylogenetic position of the Diphyllidea to other cestode orders, but it has provided some morphological characters on this taxon. Until we have knowledge of their embryonic development, degree of ovoviviparity and life cycles, it is premature to discuss the functional aspects of the ultrastructure of their vitellocytes during and after egg formation and its possible phylogenetic significance.

Acknowledgements. We wish to express our thanks to Lassad Neifar from the "Département des Sciences de la Vie, Faculté des Sciences de Sfax" (Tunisia) for his valuable help in the field work. We are also very grateful to "Unitat de Microscòpia, Facultat de Medicina, Centre Científic i Tecnològic de la Universitat de Barcelona (CCiTUB)", particularly Núria Cortadellas and Almudena García, for their support in the preparation of samples. This study was partially supported by the AECID grants No. A/2390/05 and No. A/6244/06.

\section{References}

Bruňanská M. 1997. Proteocephalus exiguus La Rue 1911 (Cestoda, Proteocephalidea): ultrastructure of the vitelline cells. Helminthologia, 34, 9-13.

Bruňanská M., Drobníková P., Oros M. 2009. Vitellogenesis in the cestode Atractolytocestus huronensis Anthony, 1958 (Caryophyllidea: Lytocestidae). Parasitology Research, 105, 647654. DOI: 10.1007/s00436-009-1436-7.

Bruňanská M., Poddubnaya L.G., Dezfuli B.S. 2005. Vitellogenesis in two spathebothriidean cestodes. Parasitology Research, 96 , 390-397. DOI: 10.1007/s00436-005-1378-7.

Ivanov V.A., Hoberg E.P. 1999. Preliminary comments on a phylogenetic study of the order Diphyllidea van Beneden in Carus, 1863. Systematic Parasitology, 42, 21-27. DOI: 10.1023/ A:1006059428150.

Janicki C. 1918. Neue Studien über post-embryonale Entwicklung und Wirtwechsel bei Bothriocephalen. I. Triaenophorus nodu- losus (Pall.). Correspondenz-Blatt für Schweizer Aerzte, 40, 1343-1349.

Jarecka L. 1961. Morphological adaptations of tapeworm eggs and their importance in the life cycles. Acta Parasitologica Polonica, 9, 409-426.

Jarecka L. 1975. Ontogeny and evolution of cestodes. Acta Parasitologica Polonica, 23, 93-114.

Levron C., Poddubnaya L.G., Kuchta R., Freeman M., Scholtz T. 2007. Vitellogenesis and vitelline system in the pseudophyllidean tapeworm Paraechinophallus japonicus: ultrastructural and cytochemical studies. Folia Parasitologica, $54,43-50$

Mackiewicz J.S. 1968. Vitellogenesis and egg-shell formation in Caryophyllaeus laticeps (Pallas) and Caryophylloides fennica (Schneider) (Cestoidea: Caryophyllidea). Zeitschrift für Parasitenkunde, 30, 18-32. DOI: 10.1007/BF00329472.

Mackiewicz J.S. 1988. Cestode transmission patterns. Journal of Parasitology, 74, 60-71.

Młocicki D., Świderski Z., Conn D.B. 2010. Ultrastructure of the early embryonic stages of Corallobothrium fimbriatum (Cestoda: Proteocephalidea). Journal of Parasitology, 96, 839846. DOI: $10.1645 / \mathrm{GE}-2438.1$.

Mokhtar-Maamouri F., Świderski Z. 1976. Vitellogénese chez Echeneibothrium beauchampi Euzet, 1959 (Cestoda: Tetraphyllidea, Phyllobothriidae). Zeitschrift für Parasitenkunde, 50, 293-302

Poddubnaya L.G., Gibson D.I., Świderski Z., Olson P.D. 2006. Vitellocyte ultrastructure in the cestode Didymobothrium rudolphii (Monticelli, 1890): possible evidence for the recognition of divergent taxa within the Spathebothriidea. Acta Parasitologica, 51, 255-263. DOI: 10.2478/s11686-006-0039-z.

Rees G. 1961. Studies on the functional morphology of the scolex and of the genitalia in Echinobothrium brachysoma Pintner and E. affine Diesing from Raja clavata L. Parasitology, 51, 193-226. DOI: 10.1017/S0031182000068591.

Ruszkowski J.S. 1927. Badania nad rozwojem i budowa tasiemców morskich. Część. I. Larwy tasiemca Echinobothrium benedeni n. sp. i jego żywiciel pośredni. Rozprawy Wydziału Matematyczno-Przyrodniczego, Series A/B, 67, 313-323.

Ruszkowski J.S. 1928. Etudes sur le cycle evolutif et sur la structure des cestodes de mer. I.-Echinobothrium benedeni n. sp., ses larves et son hôte intermediaire Hippolyte varians Leach. Bulletin de l'Académie Polonaise des Sciences et des Lettres Classe des Sciences Mathematiques et Naturelles, Serie B: Sciences Naturelles, 719-738.

Świderski Z. 1968. Electron-microscopy of embryonic envelope formation by the cestode Catenotaenia pusilla. Experimental Parasitology, 23, 113-192. DOI: 10.1016/0014-4894(68)90 048-9.

Świderski Z. 1973. Vitellogenesis in the cestode Inermicapsifer madagascariensis (Davaine, 1870) Baer, 1956. Proceedings, 48th Annual Meeting of the American Society of Parasitology, Toronto, 40.

Świderski Z., Bruňanská M., Poddubnaya L.G., Mackiewicz J.S. 2004. Cytochemical and ultrastructural study on vitellogenesis in caryophyllidean cestode Khawia armeniaca (Cholodkovski, 1915). Acta Parasitologica, 49, 16-24.

Świderski Z., Chomicz L., Grytner-Zięcina B., Tkach V. 2000. Electron microscope study on vitellogenesis in Catenotaenia pusilla (Goeze, 1782). Acta Parasitologica, 45, 83-88.

Świderski Z., Eklu-Natey R.D., Subilia L., Huggel H. 1978. Fine structure of the vitelline cells in the cestode Proteocephalus longicollis (Proteocephalidea). Proceedings, 9th International Congress of Electron Microscopy, Toronto, 422-423.

Świderski Z., Huggel H., Schönenberger N. 1970a. The role of the vitelline cell in the capsule formation during embryogenesis Brought to you by | Universidade de Aveiro Authenticated 
in Hymenolepis diminuta (Cestoda). Proceedings, 7th International Congress of Electron Microscopy, Grenoble, 669670.

Świderski Z., Huggel H., Schönenberger N. 1970b. Comparative fine structure of vitelline cells in cyclophyllidean cestodes. Proceedings, 7th International Congress of Electron Microscopy, Grenoble, 825-826.

Świderski Z., Mackiewicz J.S. 1976. Electron microscope study of vitellogenesis in Glaridacris catostomi (Cestoidea: Caryophyllidea). International Journal for Parasitology, 6, 61-73. DOI: 10.1016/0020-7519(76)90011-4.

Świderski Z., Miquel J., Młocicki D., Neifar L., Grytner-Zięcina B., Mackiewicz J.S. 2006a. Ultrastructural and cytochemical studies on vitellogenesis in trypanorhynch cestode Dollfusiella spinulifera Beveridge, Neifar et Euzet, 2004 (Eutetrarhynchidae). Acta Parasitologica, 51, 182-193. DOI:10.2478/s11 686-006-0029-1.

Świderski Z., Miquel J., Młocicki D., Neifar L., Grytner-Zięcina B., Mackiewicz J.S. 2006b. Ultrastructure of vitellocytes in the cestode Progrillotia pastinacae Dollfus, 1946 (Trypanorhyncha, Progrillotiidae). Acta Parasitologica, 51, 194-199. DOI: 10.2478/s11686-006-0030-8.

Świderski Z., Miquel J., Neifar L., Mackiewicz J.S. 2007. Ultrastructural and cytochemical studies on vitellogenesis in the trypanorhynch cestode Parachristianella trygonis Dollfus, 1946 (Eutetrarhynchidae). Acta Parasitologica, 52, 114-126. DOI: 10. 2478/s11686-007-0020-5.

Świderski Z., Młocicki D., Eira C., Miquel J., Grytner-Zięcina B., Mackiewicz J.S. 2005. Vitellogenesis in Mosgovoyia cte- noides (Railliet, 1890) Beveridge, 1978 (Cyclophyllidea, Anoplocephalidae). Acta Parasitologica, 50, 305-311.

Świderski Z., Młocicki D., Mackiewicz J.S., Miquel J., Ibraheem M.H., Bruňanská M. 2009. Ultrastructure and cytochemistry of vitellogenesis in Wenyonia virilis Woodland, 1923 (Cestoda, Caryophyllidea). Acta Parasitologica, 54, 131-142. DOI: 10. 2478/s11686-009-0028-0.

Świderski Z., Mokhtar F. 1974. Étude de la vitellogénése de Bothriocephalus clavibothrium Ariola, 1899 (Cestoda: Pseudophyllidea). Zeitschrift für Parasitenkunde, 43, 135-149. DOI: 10.1007/BF00328851.

Świderski Z., Subilia L. 1978. Electron microscopy of embryonic envelope formation by the cestode Proteocephalus longicollis (Zeder, 1800) (Proteocephalidea). Proceedings, 9th International Congress of Electron Microscopy, Toronto, 2, 444- 445.

Świderski Z., Xylander W.E.R. 1998. Types of vitellocytes and vitellogenesis in the Cestoda in relation to different types of embryonic development, ovoviviparity and life cycles. Wiadomości Parazytologiczne, 44, 604.

Świderski Z., Xylander W.E.R. 2000. Vitellocytes and vitellogenesis in cestodes in relation to embryonic development egg production and life cycles. International Journal for Parasitology, 30, 805-817. DOI: 10.1016/S0020-7519(00)00066-7.

Thiéry J.P. 1967. Mise en évidence des polysaccharides sur coupes fines en microscopie électronique. Journal de Microscopie, Paris, 6, 987-1018.

Tyler II G.A. 2006. Tapeworms of Elasmobranchs (Part II). A monograph on the Diphyllidea (Platyhelminthes, Cestoda). Bulletin of the University of Nebraska State Museum, 20, 142 pp. 